\title{
Whiteboard Animations for Flipped Classrooms in a Common Core Science General Education Course
}

\section{Ming Li, Chi Wai Lai, Wai Man Szeto}

Office of University General Education, The Chinese University of Hong Kong, Hong Kong.

\begin{abstract}
Whiteboard animation, an engaging tool for teaching and learning, consists of a series of hand-drawing illustrations with voice-over narration to explain complex and abstract ideas. Our team had produced four short whiteboard animations tailor-made for a common core science general education (GE) course. This study aims at evaluating the effectiveness of using these whiteboard animations for flipped classrooms in the common core science GE course. The pre-tutorial survey showed that students who watched the animations got significantly higher average marks in the quizzes at the beginning of the tutorials $(p<0.001)$. The post-tutorial feedback survey indicated that the whiteboard animations attracted $67 \%$ of students to watch the animations. For students who watched the animations, over $86 \%$ of them reported that the animations raised their interest in the issues discussed in the tutorial classes, and learning materials in the form of whiteboard animation were more interesting than lecture videos; more than $90 \%$ of the students agreed the whiteboard animations were helpful in (i) understanding the assigned readings, (ii) clarifying the concepts of the discussed issues, and (iii) gaining the related knowledge before the tutorial. We concluded that whiteboard animation is an effective and engaging tool for flipped classrooms in the common core science GE course.
\end{abstract}

Keywords: whiteboard animation; flipped classroom; common core; science education; general education; In Dialogue with Nature. 


\section{Introduction}

Whiteboard animation is an increasingly popular form of educational media. It consists of step-by-step illustrations with voice-over narration to explain complicated concepts and abstract ideas in an attractive and enjoyable way. The line drawings are visual design elements which influence learners’ emotions and foster learning (Um et al., 2012). For instance, Türkay (2016) demonstrated that whiteboard animations have a significant positive effect on retention, engagement, and enjoyment in conveying physics lessons. Türkay and Moulton (2016) also found that whiteboard animation is beneficial for learning in social science lessons in terms of learning and subjective experiences of enjoyment and engagement. These studies support the usefulness of whiteboard animation in specific disciplines but its effectiveness in common core courses, which students come from different disciplines, remains unexplored. Hence, we would like to study how does whiteboard animation help the teaching and learning in a common core course.

This project was carried out in the context of the common core science general education (GE) course In Dialogue with Nature in The Chinese University of Hong Kong. This course engages students in reflecting our understanding of the physical universe, the world of life, and scientific and other worldviews through the reading of great books and stories of the influential philosophers and scientists (Chan et al., 2016). Students are required to study the assigned readings before attending interactive tutorials each week. Given that about 3,600 students from different disciplines enroll in the common core course each year, students' diverse backgrounds lead to various pedagogical concerns. For instance, students without science background have lower confidence in reading science-related texts in general (Kiang et al., 2015). Lau et al. (2018) reported that science education in high school and religious background contributed to the different views on the nature of science. Teaching and learning this science classic-reading common core GE course is challenging. The lack of prerequisite knowledge, misunderstanding of concepts, inadequate comprehension of abstract ideas, and inability to connect different texts are the students' common obstacles for studying this course. Teachers need to sacrifice lots of time in the tutorial to deal with these obstacles, which means the tutorials have less time for thoughtful discussion and less productive than it could have been. Given this, we have explored the development of whiteboard animation as an innovative teaching and learning tool for flipped classrooms ( $\mathrm{Li}$ et al., 2017). In this study, we would like to evaluate the effectiveness of using these whiteboard animations for flipped classrooms in the common core science GE course. In brief, the pre-tutorial and post-tutorial feedback surveys were used to evaluate the effectiveness of the whiteboard animations in equipping students' prerequisite knowledge before and during tutorials. The engagement, motivation and habit of watching the whiteboard animations are also studied in this paper. 


\section{Methodology}

\subsection{Implementation}

Four whiteboard animations ("UGFN-animated", 2018) were tailor-made to flip the classrooms in the common core science GE course according to Li et al. (2017). Each animation is about five minutes long in two languages (English and Chinese). The two animations, "What is life?” (Figure 1) and “Does DNA determine you?”, are related to the scientific inquiry of life and were designed to flip the classrooms of the tutorials discussing James Watson's DNA: The Secret of Life. The other two, "Where does our mind come from?” and "Do we have free will?", are related to the scientific inquiry of mind and were designed for the tutorials discussing Eric Kandel’s In Search of Memory.
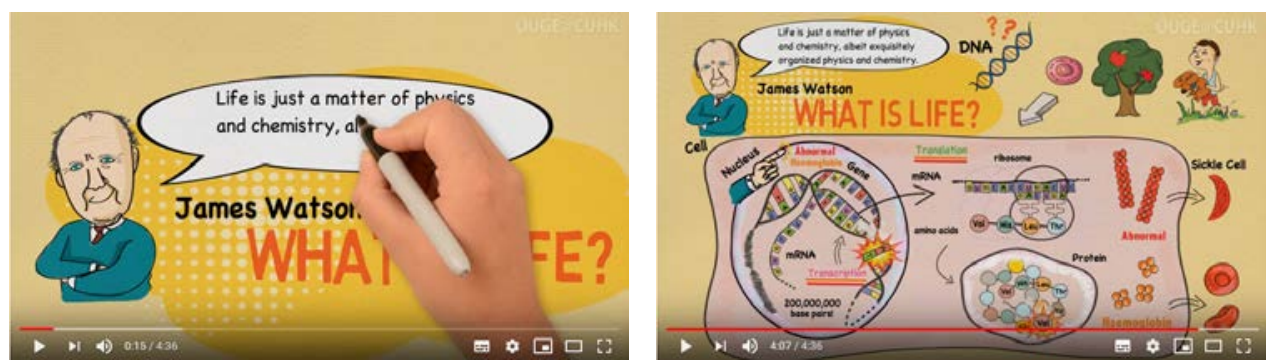

Figure 1. The whiteboard animation "What is life?” developed in this project. The left panel shows the drawing process of the illustrations. The right panel shows the big-picture.

In this study, the animations were provided to the students of 15 tutorial classes (25 students in each tutorial) in the first semester of 2016-17. To flip the classrooms, we encouraged students to watch the whiteboard animations at their own pace before attending the tutorials. During the tutorials, when students discussed the topics related to the scientific inquiries of life and mind, the big-pictures of the whiteboard animations were displayed to aid the discussions when necessary.

\subsection{Evaluation}

Two surveys were used to evaluate the effectiveness of the whiteboard animations. The aim of the first survey, the pre-tutorial survey, is to evaluate the effectiveness of the animations on equipping students with the prerequisite knowledge before the tutorials. It was conducted in the form of quizzes at the beginning of the tutorials, and more than 280 students participated in it (Table 1). For each animation, two multiple-choice questions about the prerequisite knowledge necessary for discussion in the tutorial were asked. Students were also asked to indicate whether they did or did not watch the animations. The marks of the students who did and did not watch the animations were compared using the unpaired t-test. A sample question of the quiz is given below. 
Which of the followings about the process of DNA decoding is/are correct?

i. Understanding the mechanism of gene expression means understanding the process of decoding the code of life;

ii. After transcription, the mRNA will leave the nucleus and then cut and processed;

iii. In translation, each coding unit contains two nucleotide bases.

(A) i only (B) i and ii only (C) ii and iii only (D) i and iii only (E) I do not know

The aims of the second survey, the post-tutorial feedback survey, are to collect students' feedback on the reasons of watching (and not watching) the whiteboard animations, and to evaluate to what extent these animations help them prepare the discussions in the tutorials. Students were invited to fill in the survey after the tutorials and feedbacks from 333 respondents were included in this study.

Table 1. Comparison of the quiz performance in the pre-tutorial survey between students who did and did not watch the four whiteboard animations before tutorials.

\begin{tabular}{|c|c|c|c|c|c|c|c|c|c|c|c|}
\hline & \multicolumn{2}{|r|}{ Quiz 1} & \multicolumn{3}{|c|}{ Quiz 2} & \multicolumn{3}{|c|}{ Quiz 3} & \multicolumn{3}{|c|}{ Quiz 4} \\
\hline \multirow{2}{*}{$\begin{array}{c}\text { Animation } \\
\text { Group }\end{array}$} & \multicolumn{2}{|c|}{ What is life? } & \multicolumn{3}{|c|}{$\begin{array}{c}\text { Does DNA determine } \\
\text { you? }\end{array}$} & \multicolumn{3}{|c|}{$\begin{array}{c}\text { Where does our mind } \\
\text { come from? }\end{array}$} & \multicolumn{3}{|c|}{$\begin{array}{c}\text { Do we have free } \\
\text { will? }\end{array}$} \\
\hline & Watch & Not $\Delta$ & Watch & Not & $\Delta$ & Watch & Not & $\Delta$ & Watch & Not & $\Delta$ \\
\hline Student no. & 177 & $127 \quad 50$ & 169 & 138 & 31 & 181 & 104 & 77 & 176 & 104 & 72 \\
\hline Student (\%) & 58.2 & $41.8 \quad 16.4$ & 55.0 & 45.0 & 10.1 & 63.5 & 36.5 & 27.0 & 62.9 & 37.1 & 25.7 \\
\hline 0 marks (\%) & 54.8 & $72.4-17.6$ & 33.1 & 73.9 & -40.8 & 11.6 & 72.1 & -60.5 & 13.6 & 71.2 & -57.5 \\
\hline 1 mark (\%) & 35.6 & 23.612 .0 & 34.3 & 21.7 & 12.6 & 19.3 & 22.1 & -2.78 & 34.1 & 24.0 & 10.1 \\
\hline 2 marks (\%) & 9.6 & $3.9 \quad 5.7$ & 32.5 & 4.3 & 28.2 & 69.1 & 5.8 & 63.3 & 52.3 & 4.8 & 47.5 \\
\hline $\begin{array}{c}\text { Average } \\
\text { mark }\end{array}$ & 0.55 & $0.310 .24 *$ & 0.99 & 0.30 & $0.69 *$ & 1.57 & 0.34 & $1.23^{*}$ & 1.39 & 0.34 & $1.05^{*}$ \\
\hline
\end{tabular}

$\Delta$ : The difference between students who did and did not watch the animation (i.e. "Watch" minus "Not"). *Statistical significance in the unpaired t-test with $p$-value $<0.001$.

\section{Results and discussion}

In this study, the effectiveness of using these whiteboard animations for flipped classrooms in the common core science GE course was evaluated. The pre-tutorial survey showed that $55.0 \%$ to $63.5 \%$ students, with an average of $59.9 \%$, watched the four whiteboard animations before the tutorials (Table 1). In general, students who watched the animations before the tutorials performed much better than those who did not. For example, less than $5.8 \%$ of the students who did not watch the animations got full mark (i.e. "2 marks") in the quizzes, while for those who watched the animations the percentages are much higher 
(9.6\%, 32.5\%, $69.1 \%$ and $52.3 \%$ in the quizzes 1 to 4 , respectively). More than $71.2 \%$ of the students who did not watch the animations got " 0 marks", while for those who watched the animations the percentages are much lower $(54.8 \%, 33.1 \%, 11.6 \%$ and $13.6 \%$ in the quizzes 1 to 4, respectively). For all the quizzes, students who watched the animations got significantly higher average marks than those who did not $(p<0.001$, Table 1$)$. These data suggested a significant positive correlation between watching the animations and understanding of prerequisite knowledge before tutorials. Then, the areas of how and to what extent these animations helped students prepare the discussions in the tutorials were investigated. In the post-tutorial feedback survey, 67.3\% students reported that they had watched the whiteboard animations. 92.1\% of these students agreed in different degrees (including "slightly agreed”, "agreed”, and "strongly agreed”) that the animations were helpful in gaining the knowledge of life and mind before tutorials (Figure 2). 90.9\% and $92.7 \%$ of the students agreed the animations were helpful in understanding the texts and in clarifying the concepts of the discussed issues, respectively. All these findings indicated that the animations helped equip students with the prerequisite knowledge before tutorials.

- Whiteboard animation is more interesting than lecture video.

- These animations have raised your interest in the discussed issues.

- These animations are helpful for your understanding of the texts.

- These animations are helpful in clarifying the concepts of the discussed issues.

- These animations are helpful in gaining the knowledge of life and mind before tutorials.

- These animations are helpful for the discussion in tutorials.

- These animations are helpful for your reflections on cross-text issues.

- The level of difficulty of these animations is appropriate.

In general, you are satisfied with these animations.

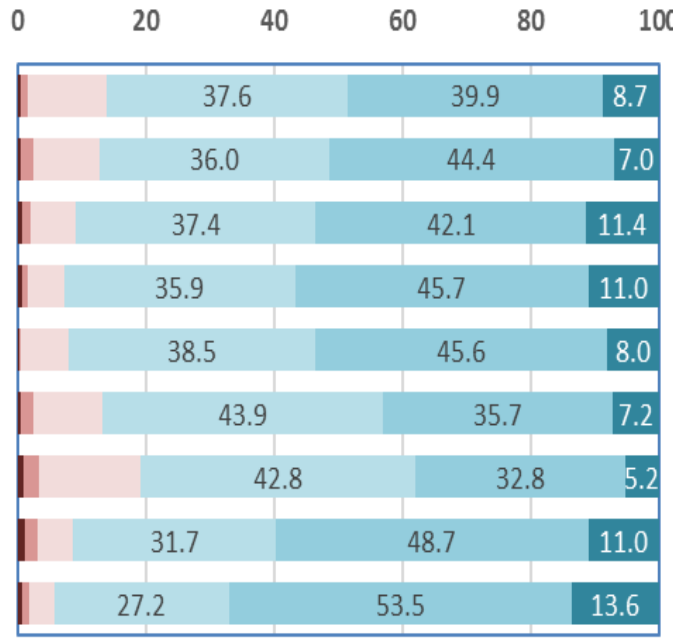

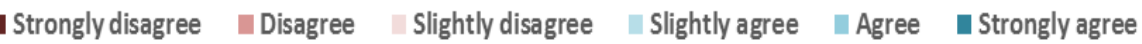

Figure 2. Views from the students who watched the whiteboard animations in the post-tutorial feedback survey. A six-point Likert scale (from 1 "strongly disagree" to 6 "strongly agree") was used to indicate the degree of agreement on the statements. The figures are in percentage.

The next question asked was whether the whiteboard animations are helpful for discussion during the tutorials. The feedback survey revealed that $86.8 \%$ of the students agreed these animations were helpful for the tutorial discussions (Figure 2). This finding is in line with the observations of the teachers that some students used the examples in the whiteboard 
animations to support their arguments during the tutorial discussions. Some students referred to the concepts in the whiteboard animations to refute their classmates' arguments, correct their mistakes, and clarify the concepts. Also, $80.8 \%$ of the students agreed that the animations helped them reflect on issues across different texts. All these findings indicated that the animations are useful for students to better prepare for and discuss in the tutorials. Some of their comments in the feedback survey are shown below.

"The content is interesting. The animations are lively and help me understand the content"; "The expression and explanation in the whiteboard animations are clear and concise. They bring up questions for reflection.”;

"The whiteboard animations are clear. They are helpful for understanding and learning, especially for students who didn't study biology [in high school]".

These encouraging comments suggested that the animations were well received by the students. In particular, students who did not have the science background may find this course intimidating. Hoi et al. (2017) showed that $60-70 \%$ of students studying the common core science GE course reported science anxiety and the anxiety situation varied among faculties. This is one of the reasons to tailor-make the whiteboard animations to suit the need of non-science students. With careful design of the storyboard, the whiteboard animations can provide the prerequisite knowledge required by the course at an appropriate level. In this project, $91.4 \%$ of the students thought that the level of difficulty of the four animations is appropriate, and $94.3 \%$ of the students were satisfied with the animations in general (Figure 2).

While effectiveness is one of the major concerns, how to engage the students is another key issue worth studying. Overall, $87.4 \%$ of the students said that the animations had raised their interest in the issues discussed in the tutorial classes and $86.2 \%$ of the students agreed that learning materials in the form of whiteboard animation are more interesting than lecture video (Figure 2). These data aligned with a recent report that our whiteboard animations are more effective and interesting than studio recorded lectures and recorded student discussion (Cheung et al., 2018). Although the animations had already attracted more than two-thirds of the students, we would like to explore how to engage more students by knowing their motivations and habits of watching the animations. Students were asked to indicate why (or not) and when they watched the animations by checking one or more options in the post-tutorial feedback survey.

For motivation, most of the students watched the animations due to their teachers' recommendation (89.2\%, Table 2) which suggested that promotion by teachers is the most important. 37.3\% students said they wanted to learn from the animations. 50.9\% and $42.7 \%$ of the students watched the animations when reading the texts and studying the lecture PowerPoint slides, respectively, and $15.1 \%$ students watched the animations 30 minutes 
right before the tutorials. These data suggested that some students valued the animations as study companions when studying the course materials and preparing for the tutorials. $27.9 \%$ and $22.1 \%$ of the students reported that they were interested in the topics and were curious about the animations, respectively, which implied the content of the animations and the new learning experience contributed to the motivation of watching. Among the $67.3 \%$ students who watched the animations, most of them (84.1\%) watched the animations for one time, while $15.9 \%$ students watched them twice or more (Table 2). It is noted that the students who did not watch the animations were mainly because of mere forgetfulness (47.7\%) and having no time to watch (55.7\%). Ensuring students to watch the online materials is challenging in flipped classroom practices which assume students' responsibility for their own learning. Sending reminders, setting assignments and formal quizzes may help. In this study, we have shown the effectiveness and engagingness of whiteboard animations. We hope that understanding students' motivations and habits of watching can provide useful insights into the development of better whiteboard animations to support teaching and learning. 
Table 2. Motivations and habits of watching and not watching the whiteboard animations collected in the post-tutorial feedback survey.

\begin{tabular}{|c|c|c|c|c|c|c|c|}
\hline $\begin{array}{l}\text { Why did you } \\
\text { watch the } \\
\text { animations? }\end{array}$ & Option & $\begin{array}{c}\text { Recommended } \\
\text { by teacher }\end{array}$ & $\begin{array}{l}\text { Recommended } \\
\text { by friends or } \\
\text { classmates }\end{array}$ & $\begin{array}{l}\text { Interested } \\
\text { in the } \\
\text { topic }\end{array}$ & $\begin{array}{c}\text { Out of } \\
\text { curiosity }\end{array}$ & $\begin{array}{l}\text { Want to learn } \\
\text { from the } \\
\text { animations }\end{array}$ & Others \\
\hline $\begin{array}{c}\text { (can choose } \\
\text { multiple } \\
\text { options) }\end{array}$ & Student (\%) & 89.2 & 2.8 & 27.9 & 22.1 & 37.3 & 2.4 \\
\hline \multirow{2}{*}{$\begin{array}{l}\text { When did you } \\
\text { watch the } \\
\text { animations? } \\
\text { (can choose } \\
\text { multiple } \\
\text { options) }\end{array}$} & Option & $\begin{array}{l}\text { When taking the } \\
\text { school bus }\end{array}$ & $\begin{array}{l}\text { When taking } \\
\text { other } \\
\text { transportation }\end{array}$ & $\begin{array}{l}\text { When } \\
\text { studying } \\
\text { lecture } \\
\text { slides }\end{array}$ & $\begin{array}{l}\text { When } \\
\text { reading } \\
\text { the texts }\end{array}$ & $\begin{array}{c}\text { Within } 30 \\
\text { minutes before } \\
\text { tutorials }\end{array}$ & Others \\
\hline & Student (\%) & 1.5 & 2.1 & 42.7 & 50.9 & 15.1 & 11.8 \\
\hline \multirow{2}{*}{$\begin{array}{c}\text { How many } \\
\text { times have } \\
\text { you watched } \\
\text { the animations } \\
\text { on average? }\end{array}$} & No. of time & One & Two & Three & Four & Five & > Five \\
\hline & Student (\%) & 84.1 & 13.5 & 1.4 & 0.9 & 0.2 & 0 \\
\hline \multirow{2}{*}{$\begin{array}{l}\text { Why didn't you } \\
\text { watch the } \\
\text { animations } \\
\text { (can choose } \\
\text { multiple } \\
\text { options) }\end{array}$} & Option & $\begin{array}{l}\text { Didn't know } \\
\text { they exist }\end{array}$ & $\begin{array}{l}\text { Didn't have } \\
\text { time }\end{array}$ & $\begin{array}{l}\text { Not } \\
\text { interested } \\
\text { in the } \\
\text { topic }\end{array}$ & $\begin{array}{c}\text { Forgot to } \\
\text { watch }\end{array}$ & $\begin{array}{l}\text { Already good at } \\
\text { the topic }\end{array}$ & Others \\
\hline & $\overline{\text { Student (\%) }}$ & 5.7 & 55.7 & 3.0 & 47.7 & 5.4 & 6.8 \\
\hline
\end{tabular}

\section{Limitations of the study}

The pre-tutorial survey shows a correlation between watching the animations and understanding of prerequisite knowledge before tutorials. One should note that it is a significant positive correlation but does not necessarily imply causation. We cannot exclude the possibility that students who watched the animations are more active, attentive, hardworking, knowledgeable, and hence lead to better performance in the quizzes. Besides, some students in this study may not have experienced learning using lecture videos. Their response to the related question ("whiteboard animation is more interesting than lecture video”) in the post-tutorial feedback survey may not be accurate. A rigorous study to compare the effect of these two forms of teaching and learning materials using the same content and under the same context would be the most insightful. 


\section{Conclusions}

Technology advancement has assuredly benefited teaching and learning in this digital era. This study showed that the tailor-made whiteboard animations helped students prepare better before coming to class, raise students' interest in the discussion topics, and deepened their discussion and reflection in the tutorials. These animations are effective and engaging tools for flipped classrooms in the common core science GE course. They provide a unique learning experience for the students which make learning easy and fun.

\section{Acknowledgments}

We want to thank the Centre for eLearning and Innovation Technology of The Chinese University of Hong Kong for their support. This project was funded by the Micro-module Courseware Development Grant Scheme.

\section{References}

Chan, C. C., Szeto, W. M., \& Wong, W. H. (Eds.). (2016). In Dialogue with Nature: Textbook for General Education Foundation Programme. Hong Kong: Office of University General Education.

Cheung, H. C. D., Ng, K. L. A, \& Wong, K. T. I. (2018) Diversity in video learning: a cost-effective comparison of four video types. Teaching and Learning Innovation Expo 2018. Retrieved from

https://www.elearning.cuhk.edu.hk/expo2018-talk/T9.

Hoi, W. H. S., Wong, W. H., \& Pang, K. M. (2017). Confronting students' science anxiety through "In Dialogue with Nature." The European Conference on Education 2017 (ECE2017). Retrieved from The IAFOR Research Archive. Retrieved from https://papers.iafor.org/submission36285/.

Kiang, K. M., Chan, H., Ng, A. K., \& Cheung, D. H. (2016). Effectiveness of micromodules in a science classics course. American Journal of Educational Research, 4(13), 917-926. doi: 10.12691/education-4-13-1.

Kiang, K. M., Ng, A. K., \& Cheung, D. H. (2015). Teaching science to non-science students with science classics. American Journal of Educational Research, 3(10), 12911297. doi: 10.12691/education-3-10-13.

Lau, K. C., Li, M., \& Liao, L. (2018). Assessment of students' views of nature of science in the context of the discovery of DNA structure. Proceedings of MAC 2018 in Prague, 196-216.

Li, M., Lai, C. W., \& Szeto, W. M. (2017). Whiteboard animation: an innovative teaching and learning tool for flipped classrooms. In C. Nygaard, A. Horsted, J. Branch, \& P. Bartholomew (Eds.), New Innovations in Teaching and Learning in Higher Education (pp. 159-175). Oxfordshire, United Kingdom: Libri Publishing. 
Türkay, S. (2016). The effects of whiteboard animations on retention and subjective experiences when learning advanced physics topics. Computers \& Education, 98(1), 102-114.

Türkay, S., \& Moulton, S. T. (2016). The educational impact of whiteboard animations: an experiment using popular social science lessons. Proceedings from LINC 2016, 283291.

UGFN-animated. (2018). In Office of University General Education, CUHK. Retrieved Jan 30, 2019, from http://www.cuhk.edu.hk/oge/gef-animated/en/ugfn.html.

Um, E. R., Plass, J. L., Hayward, E. O., \& Homer, B. D. (2012). Emotional design in multimedia learning. Journal of Educational Psychology, 104(2), 485-498. doi: 10.1037/a0026609. 